\title{
Milling yield components of local dryland rice varieties ${ }^{1}$
}

\author{
Otavio Rechsteiner Maghelly ${ }^{2}$, Juliana Bernardi Ogliari ${ }^{3}$, \\ Rosenilda de Souza ${ }^{4}$, Francisco Wilson Reichert Júnior ${ }^{3}$, Tassiane Terezinha Pinto ${ }^{5}$
}

\section{ABSTRACT}

Family farmers in the western Santa Catarina state, Brazil, have conserved local dryland rice varieties. However, the literature lacks data about the milling performance of these varieties, as well as about the effects of genotypes, environment and genotype $\mathrm{x}$ environment interaction. The current study aimed to evaluate the milling yield, as well as whole, broken, white-belly and chalky grains, in experiments designed in complete randomized blocks, with four replications, in two sites. The rates for milling yield and whole and broken grains were, respectively, 57.93-69.90\%, 38.73-66.0 \% and 3.40$22.15 \%$, with 15 local varieties reaching values similar to those recorded for modern dryland rice varieties. The Anchieta county (origin of the varieties) recorded the highest values for milling yield and whole grain. The incidence rates for white-belly and chalky grains were, respectively, $0.10-8.68 \%$ and $0.02-3.12 \%$. Significant differences $(\mathrm{p} \leq 0.05)$ were observed for genotype, environment and genotype $\mathrm{x}$ environment interaction effects, concerning the milling yield. For whole and broken grains, the differences were significant $(\mathrm{p} \leq 0.05)$ for genotype and environment, but not significant for genotype $\mathrm{x}$ environment interaction. For white-belly and chalky grains, the differences were significant $(p \leq 0.05)$ for genotype and genotype $x$ environment interaction, but not significant for environment. For all the studied milling yield variables, differences were observed for the varieties' stability, as well as established a stability ranking.

KEYWORDS: Oryza sativa, milling yield, genotype $\mathrm{x}$ environment interaction.

\section{INTRODUCTION}

Family farmers in the western Santa Catarina state, Brazil, traditionally grow local dryland

\section{RESUMO}

Componentes de rendimento industrial de variedades locais de arroz de sequeiro

Variedades locais de arroz de sequeiro vêm sendo conservadas por agricultores familiares do oeste catarinense. Contudo, não existem dados na literatura sobre a qualidade e o rendimento industrial dessas variedades, bem como dos efeitos dos genótipos, do ambiente e da interação genótipo x ambiente. Avaliaram-se a renda de benefício e grãos inteiros, quebrados, barrigas brancas e gessados, em experimentos delineados em blocos completos casualizados, com quatro repetições, em dois locais. A renda e a taxa de grãos inteiros e quebrados foram de 57,93-69,90 \%, 38,73$66,0 \%$ e 3,40-22,15\%, respectivamente, com 15 variedades locais atingindo valores semelhantes aos obtidos por variedades modernas de arroz de sequeiro. Os maiores valores para renda e grãos inteiros foram obtidos em Anchieta (local de procedência das variedades). Os percentuais de ocorrência de grãos barriga branca e gessados foram de $0,10-8,68 \%$ e $0,02-3,12 \%$, respectivamente. As diferenças foram significativas $(\mathrm{p} \leq 0,05)$ para os efeitos do genótipo, ambiente e interação genótipo $\mathrm{x}$ ambiente, para a renda de benefício. Para grãos inteiros e quebrados, as diferenças foram significativas $(\mathrm{p} \leq 0,05)$ para genótipo e ambiente, mas não para a interação genótipo x ambiente. Para grãos barriga branca e gessados, as diferenças resultaram significativas $(\mathrm{p} \leq 0,05)$ para genótipo e interação, e não significativas para ambiente. Foram observadas diferenças quanto à estabilidade das variedades, em relação a todas as variáveis de rendimento industrial estudadas, e estabelecido um ranking de estabilidade.

PALAVRAS-CHAVE: Oryza sativa, rendimento de engenho, interação genótipo x ambiente.

rice varieties for self-consumption purposes and, occasionally, they sell them in the local market.

Although the total area planted with dryland rice in the Santa Catarina state has decreased by

\footnotetext{
${ }^{1}$ Received: Aug. 18, 2020. Accepted: Sep. 23, 2020. Published: Oct. 20, 2020. DOI: 10.1590/1983-40632020v5065085.

${ }^{2}$ Universidade Federal de Santa Catarina, Centro de Ciências Agrárias, Fazenda Experimental da Ressacada, Florianópolis, SC, Brasil. E-mail/ORCID: otavio.maghelly@ufsc.br/0000-0001-9918-4177.

${ }^{3}$ Universidade Federal de Santa Catarina, Centro de Ciências Agrárias, Departamento de Fitotecnia, Florianópolis, SC, Brasil. E-mail/ORCID: juliana.bernardi@ufsc.br/0000-0003-2644-3179, chicowrj@gmail.com/0000-0002-4501-898X.

${ }^{4}$ Empresa Brasileira de Pesquisa Agropecuária (Embrapa), Brasília, DF, Brasil. E-mail/ORCID: rosenilda.agro@hotmail.com/0000-0001-7820-2516.

${ }^{5}$ Universidade Federal de Santa Catarina, Centro de Ciências Biológicas, Departamento de Botânica, Florianópolis, SC, Brasil. E-mail/ORCID: tassi.tp@gmail.com/0000-0001-6575-7635.
} 
$99 \%$ in the last three decades, the mean yield of this crop has not changed significantly, since values remain in the range of 1,500-2,000 $\mathrm{kg} \mathrm{ha}^{-1}$ (Embrapa 2019). Among the main reasons for the significant reduction in the total area planted with dryland rice, a low industrial quality and a significant qualitative grain variation stand out (Santos et al. 2006), in comparison to irrigated rice.

Milling quality is a determining factor featuring the rice variety potential, while milling yield - which is based on the sum of whole and broken grains, after husking and polishing, without counting husk and bran - is one of the main industrial quality aspects of rice varieties. Another fundamental industrial quality aspect lies on the whole and broken grain yield. Whole and broken grain rates affect the classification and market value of the product itself, as well as of its by-products (Castro et al. 1999, Brasil 2012). Broken grains are defined as the husked and polished piece of rice grain that corresponds to less than three quarters of the minimum length of the prevalent class (Brasil 2009). In addition, husked and polished whole grain dimensions are classified as long thin, long, medium, short and mixed (Brasil 2012).

Several biotic and abiotic stress types, such as hydric variation amplitudes, pest attacks and diseases, among others (Castro et al. 1999), may affect the whole grain yield. Rice varieties present different genetic potentials for whole-grain production, due to their susceptibility to present cracks or fissures, when they are subjected to climatic variations during the grain maturation process. Relative humidity and temperature are the main climate elements influencing the crack formation in rice grains (Santos 2012). Grain humidity at the harvesting point and quality of grain-drying processes also affect the whole grain yield. Water levels of $18.5-20.6 \%$ in rice grains were reported to enable the highest whole grain values (Smiderle \& Dias 2008).

Another aspect of milling quality lies on the incidence of chalky grains, defined as "peeled and polished grains, either whole or broken, which present opaque color similar to that of chalk" (Brasil 2009). Aspects such as the genetic quality of cultivars, cultural treatments, environmental conditions and harvest humidity influence the incidence of chalky grains.

The white-belly incidence has commercial relevance (Santos 2012), although it is not classified as a defect (Brasil 2012), and it does not affect the chemical and nutritional quality of rice grains. Whitebelly grains present plastering in the peripheral part of the endosperm (Santos 2012).

The milling yield and industrial quality of rice grains are quantitative parameters ruled in a complex way. Thus, it is necessary to understand the effects of genotype, environment and genotype $\mathrm{x}$ environment interaction on the expression of these parameters at the time to evaluate genotypes and breeding processes (Facchinelo 2017). Kibanda \& Luzi-Kihupi (2007) have reported the scarcity of published data on genotype $\mathrm{x}$ environment interactions and milling yield features, mainly with respect to dryland genotypes. Similarly, the literature lacks data on the stability of local rice varieties investigated in the current study. Stability is herein understood, based on Mariotti et al. (1976), as the ability of a given genotype to present highly predictable performance under different environmental conditions.

Thus, the present study aimed to analyze the main milling yield variables of local rice dryland varieties grown in the western Santa Catarina state, as well as their genotype $\mathrm{x}$ environment interactions and stability, in two different experimental sites.

\section{MATERIAL AND METHODS}

Experiments were conducted in a smallscale farm in the Anchieta county, as well as at the experimental farm of the Universidade Federal de Santa Catarina (UFSC), in Florianópolis, Santa Catarina state, Brazil. Anchieta is located in southern Brazil, in the far west microregion (IBGE 2010) (26 $30^{\circ} 53.93^{\prime \prime} \mathrm{S}, 53^{\circ} 18^{\prime} 44.97^{\prime}$ 'W and altitude of $717 \mathrm{~m}$ ). This region has a humid mesothermal climate (Cfa - Köppen), mean annual temperature of $17.8^{\circ} \mathrm{C}$ and annual rainfall rates of 1,700-2,000 mm (IBGE 2010). The experimental farm in Florianópolis $\left(27^{\circ} 41^{\prime} 06.28^{\prime \prime}\right.$ 'S , 48³2'38.81'W and altitude of $5 \mathrm{~m}$ ), according to the Köeppen's climatic classification, is located in a subtropical sub-region, which presents constantly humid subtropical climate, no dry season, hot summer and mean annual temperature of $20.1{ }^{\circ} \mathrm{C}$. The rainfall rate often ranges from 1,270 to $1,600 \mathrm{~mm}$, on a yearly basis (IBGE 2010). The soil in the Anchieta farm is classified as a Cambisol, with wavy and stony terrain, whereas the soil in the experimental farm is classified as a hydromorphic quartz soil.

The local rice varieties investigated in the present study were collected by the agrobiodiversity 
research group of the University Federal de Santa Catarina (NEABio/UFSC), together with farmers from Anchieta and Guaraciaba, counties in the far west of the Santa Catarina state, from 2012 to 2014. These varieties are part of the UFSC rice germplasm bank, where they are currently identified and preserved. They were selected for these experiments based on morphological and phenological dissimilarities of populations evaluated by Pinto et al. (2019). A total of thirty-four varieties were selected to represent - with more than $95 \%$ of accuracy - the genetic diversity observed in the two counties, based on the following features: number of tillers, stem thickness and panicle length. Pinto et al. (2019) had previously classified these varieties in four different classes, by taking into consideration their grain size (Brasil 2012) (Table 1). IPR117 (Iapar/ PR), which is the only dryland rice variety with commercial seed production and recommendation for cultivation in southern Brazil (long thin class), was used as a statistical control variety.

The experiments conducted in both environments followed the technology mostly used by farmers in the region, which comprises tractorizationbased soil preparation, total organic fertilization with chicken manure at planting time (calculated and performed based on soil analysis carried out at each site) and manual weeding to control invasive plants. No pest or disease control was performed.

The experiments followed a complete randomized block design, with four replications at each site. Each experimental unit comprised four $3.0-\mathrm{m}$ rows, spaced $0.34 \mathrm{~m}$ apart, and planted with 55 plants $\mathrm{m}^{-1}$. The two central meters of the two middle rows were considered the useful plot, forming a useful area of $1.36 \mathrm{~m}^{2}$, with approximately 220 plants (approximate density of 1.6 million plants ha-1).

The grains were harvested at the useful plots by manually threshing the plants' panicle. After the grain weighing procedure was over, the humidity was measured in an instant electronic measuring device (Dicke_Jonh, Multigrain model). All the harvested plots, at both sites, presented a field moisture of $18-22 \%$. The harvested grains were dried in an oven, at the temperature of $42-45{ }^{\circ} \mathrm{C}$, until they reached a moisture content of 11.8-13.6\%. A dry grain sample $(100 \mathrm{~g})$ was selected from each experimental unit and processed in a Suzuki testing mill (model MT-190). The equipment had been calibrated for long thin grains in March 2019.

The milling yield and whole and broken grain rates were recorded. After each sample was processed, the broken grains were subjected to visual evaluation in trough equipment (Brasil 2009). Varieties presenting mid-sized grains $(19,54,59$ and $60)$ required the manual separation of broken grains in the trough and their re-weigh, in order to define the total weight of whole grains. Affected grains in three samples, comprising 100 whole grains from each plot, were manually counted, to enable the analysis of white-belly and chalky grain rates. White-belly and chalky grains were weighed using an electronic scale ( $0.1 \mathrm{~g}$ accuracy) and the rate of each type was calculated in comparison to the total percentage of whole grains.

A joint analysis of variance was performed based on the mixed mathematical-statistical model by Searle et al. (1992): $Y_{i j k}=m+G_{i}+B / A_{j k}+A_{j}+$ $\mathrm{GA}_{\mathrm{ij}}+\mathrm{E}_{\mathrm{ijk}}$ (with a fixed effect for environments and a random effect for genotypes and other effects of the model), wherein: $Y_{\mathrm{ijk}}$ is the phenotypic value of the $i$-th genotype in the $j$-th environment and in the $\mathrm{k}$-th block; $\mathrm{m}$ the overall parametric mean; $\mathrm{G}_{\mathrm{i}}$ the effect of the genotype $\mathrm{i} ; \mathrm{B} / \mathrm{A}_{\mathrm{jk}}$ the block within the environment in the $\mathrm{j}$-th environment and k-th block; $A_{j}$ the effect of the environment $j ; G_{i j}$ the effect of the interaction between the $i$-th genotype and the $j$-th environment; and $\mathrm{E}_{\mathrm{ijk}}$ the effect of the experimental error associated with the $\mathrm{Y}_{\mathrm{ijk}}$ observation.

In order to perform the analysis of variance, the homogeneity of residual mean squares relative to the

Table 1. Classification of local varieties based on grain size (adapted from Pinto et al. 2019).

\begin{tabular}{ll}
\hline \multicolumn{1}{c}{ Grain classes } & \multicolumn{1}{c}{ Local varieties $^{\mathbf{1}}$} \\
\hline Long thin & $12,13,17,29,35,50,61,67,68,83,84,98,104$ \\
Long & $7,10,14,22,24,31,32,34,41,42,43,71,72,82,90,103$ \\
Medium & $19,54,59,60$ \\
Mixed & 20 \\
\hline
\end{tabular}

${ }^{1}$ Identified by access-collection number. 
experiments conducted at both sites was previously evaluated by observing whether the association between the largest and the smallest residual mean square was lower than seven, as suggested by Pimentel-Gomes (1990). The stability and genotype $x$ environment interaction were subjected to analysis of variance and comparison of means between the sites. The stability analyses were based on the traditional method described in Cruz \& Regazzi (2001) and, subsequently, the rice varieties were ordered based on their mean position, regarding the five analyzed milling variables.

Variables showing significant differences between the treatments in the analysis of variance, at a $5 \%$ significance level $(\mathrm{p} \leq 0.05)$ by the $\mathrm{F}$ test, were subjected to the Scott-Knott test, at the same significance level. All statistical analyses were performed using the Genes software (Cruz 2013).

\section{RESULTS AND DISCUSSION}

The mean milling yield in Anchieta was $67.97 \%$ (it ranged from $64.27 \%$ to $69.90 \%$ ); while, in Florianópolis, it was $63.81 \%$, ranging from $57.93 \%$ to $67.76 \%$ (Table 2). There was a trend of higher milling yield values in Anchieta. Twenty-five varieties and the control $(73 \%$ of the treatments) presented a higher milling yield at this site (Table 2). Twenty-two local varieties grown in Anchieta recorded milling yield values above the market standard (Cepea 2015) and above those required by processing industries $(68 \%)$. Nine varieties grown in Anchieta (13, 22, 34, 43, 61, 67, 68,72 and 84) were among the most productive of the twenty-two varieties presenting the best milling yield performance at the place of origin, with a yield ranging from 2,500 to 3,300 $\mathrm{kg} \mathrm{ha}^{-1}$ (Maghelly 2020). None of the investigated varieties has reached this milling yield level in Florianópolis. Artigiani et al. (2012), who investigated a modern dryland rice variety (BRS Primavera), recorded higher milling yield values at the order of $74 \%$. This outcome shows the potential of these local varieties, since they recorded milling yield values equivalent to those registered for modern commercial varieties, although they did not undergo formal breeding processes. Processing industries currently require milling yield values of approximately 68-72\% in southern Brazil. Milling yield values lower than $68 \%$ reduce the price paid to farmers (Cepea 2015).
The mean whole grain yield recorded $55.31 \%$, ranging from $33.05 \%$ to $66.00 \%$, in Anchieta; whereas the mean whole grain yield recorded in Florianópolis was $53.76 \%$, and ranged from $38.73 \%$ to $60.23 \%$. Anchieta recorded the highest whole grain yield. Twenty-nine varieties and the control ( $86 \%$ of the treatments), among the thirtyfour investigated varieties, presented a higher whole grain yield in Anchieta (Table 2). The market standard (58\%) set for whole grains (Cepea 2015) was met by $46 \%$ of the varieties grown in Anchieta, and by only $9 \%$ in Florianópolis. The varieties 13, 43, 72 and 84 exceeded the market standard set for whole grains, among the ones presenting the highest yield and best milling yield in Anchieta (Maghelly 2020). Among the improved dryland rice varieties recommended for the central-western and northern Brazil (Embrapa 2018), $80 \%$ recorded $62 \%$ for whole grain-yield potential or lower. Nine varieties grown in the place of origin recorded yields higher than $62 \%$. These values were similar to the ones recorded by Artigiani et al. (2012) for modern dryland varieties. On the other hand, twenty-four varieties recorded whole grain yields higher than $52 \%$, being lower than the potential yield value set for officially recommended dryland varieties (BRS Pepita). According to Pereira \& Rangel (2001), whole grain yields lower than $50 \%$ make the selection of cultivars for genetic breeding processes unfeasible. Seven varieties investigated in the current study recorded whole grain yields below this level in the region of origin (19, 31, 34, 59, 61, 82 and 103). According to Farias Filho \& Ferraz Júnior (2009), the whole grain yield is affected by grain size and shape. Based on their results, the genotype presenting a longer length and smaller width recorded the lowest yield.

Varieties classified in the current study as mid-sized (Table 1), shorter and wider, recorded lower whole grain yields. Although whole grains belonging to this class were manually separated in the trough, the herein used mill was regulated and calibrated for long thin grains, and it may have caused a greater breakage of grains belonging to the mid-sized class.

Anchieta recorded a mean broken grain rate equal to $12.66 \%$, which was similar to that recorded for Florianópolis $(12.58 \%)$. Values recorded for white-belly grains in Anchieta ranged from $0.08 \%$ to $8.35 \%$, with a mean value of $2.40 \%$. Values recorded for white-belly grains in Florianópolis 
Table 2. Percentage of milling yield and whole and broken grains in dryland rice, based on joint analysis of variance, in Anchieta (Anc) and Florianópolis (Fln), in 2018/2019.

\begin{tabular}{|c|c|c|c|c|c|c|c|c|c|}
\hline \multirow{2}{*}{ Local varieties } & \multicolumn{3}{|c|}{ Milling yield $(\%)$} & \multicolumn{3}{|c|}{ Whole grains $(\%)$} & \multicolumn{3}{|c|}{- Broken grains $(\%)$} \\
\hline & Anc & Fln & Mean & Anc & Fln & Mean & Anc & $F \ln$ & Mean \\
\hline 7 & $69.40 \mathrm{aA}$ & $66.66 \mathrm{aA}$ & $68.03 \mathrm{a}$ & $66.00 \mathrm{aA}$ & $53.86 \mathrm{bB}$ & $59.93 \mathrm{a}$ & $3.40 \mathrm{aB}$ & $12.80 \mathrm{cA}$ & $8.10 \mathrm{a}$ \\
\hline 10 & $67.90 \mathrm{aA}$ & $63.73 \mathrm{bB}$ & $65.82 \mathrm{a}$ & $54.13 \mathrm{bA}$ & $49.66 \mathrm{bA}$ & $51.90 \mathrm{~b}$ & $13.76 \mathrm{cA}$ & $14.06 \mathrm{dA}$ & $13.92 \mathrm{c}$ \\
\hline 12 & $69.15 \mathrm{aA}$ & $65.93 \mathrm{aB}$ & $67.54 \mathrm{a}$ & $64.70 \mathrm{aA}$ & $52.26 \mathrm{bB}$ & $58.48 \mathrm{a}$ & $4.45 \mathrm{aB}$ & $13.66 \mathrm{cA}$ & $9.06 \mathrm{a}$ \\
\hline 13 & $69.46 \mathrm{aA}$ & $64.50 \mathrm{bB}$ & $66.98 \mathrm{a}$ & $63.40 \mathrm{bA}$ & $55.90 \mathrm{aA}$ & $59.65 \mathrm{a}$ & $6.06 \mathrm{aA}$ & $8.60 \mathrm{bA}$ & $7.33 \mathrm{a}$ \\
\hline 14 & $67.53 \mathrm{aA}$ & $66.80 \mathrm{aA}$ & $67.17 \mathrm{a}$ & $50.26 \mathrm{cB}$ & $59.30 \mathrm{aA}$ & $54.78 \mathrm{~b}$ & $17.26 \mathrm{dA}$ & $7.50 \mathrm{bB}$ & $12.38 \mathrm{~b}$ \\
\hline 17 & $68.50 \mathrm{aA}$ & $64.80 \mathrm{bB}$ & $66.65 \mathrm{a}$ & $53.70 \mathrm{bA}$ & $54.60 \mathrm{bA}$ & $54.15 \mathrm{~b}$ & $14.80 \mathrm{dA}$ & $10.20 \mathrm{bA}$ & $12.50 \mathrm{~b}$ \\
\hline 19 & $65.93 \mathrm{bA}$ & $60.10 \mathrm{cB}$ & $63.02 \mathrm{c}$ & $34.86 \mathrm{cB}$ & $49.80 \mathrm{bA}$ & $42.33 \mathrm{~d}$ & $31.06 \mathrm{dA}$ & $10.30 \mathrm{bB}$ & $20.68 \mathrm{~d}$ \\
\hline 20 & $66.35 \mathrm{bA}$ & $61.66 \mathrm{cB}$ & $64.01 \mathrm{~b}$ & $56.10 \mathrm{bA}$ & $43.33 \mathrm{cB}$ & $49.72 \mathrm{c}$ & $10.25 \mathrm{bB}$ & $18.33 \mathrm{dA}$ & $14.29 \mathrm{c}$ \\
\hline 22 & $69.80 \mathrm{aA}$ & $63.66 \mathrm{bB}$ & $66.73 \mathrm{a}$ & $56.40 \mathrm{bA}$ & $52.80 \mathrm{bA}$ & $54.60 \mathrm{~b}$ & $13.40 \mathrm{cA}$ & $10.86 \mathrm{bA}$ & $12.13 \mathrm{~b}$ \\
\hline 24 & $68.53 \mathrm{aA}$ & $61.12 \mathrm{cB}$ & $64.83 \mathrm{~b}$ & $62.53 \mathrm{aA}$ & $45.87 \mathrm{cB}$ & $54.20 \mathrm{~b}$ & $6.00 \mathrm{aB}$ & $15.25 \mathrm{dA}$ & $10.63 \mathrm{~b}$ \\
\hline 29 & $68.80 \mathrm{aA}$ & $65.75 \mathrm{aB}$ & $67.28 \mathrm{a}$ & $61.26 \mathrm{aA}$ & $50.20 \mathrm{bB}$ & $55.73 \mathrm{~b}$ & $7.53 \mathrm{aB}$ & $15.55 \mathrm{dA}$ & $11.54 \mathrm{~b}$ \\
\hline 31 & $66.87 \mathrm{bA}$ & $64.05 \mathrm{bA}$ & $65.46 \mathrm{~b}$ & $44.72 \mathrm{cB}$ & $53.80 \mathrm{bA}$ & $49.26 \mathrm{c}$ & $22.15 \mathrm{dA}$ & $10.25 \mathrm{bB}$ & $16.20 \mathrm{~b}$ \\
\hline 32 & $65.13 \mathrm{bA}$ & $65.20 \mathrm{bA}$ & $65.17 \mathrm{~b}$ & $50.26 \mathrm{cA}$ & $54.86 \mathrm{bA}$ & $52.57 \mathrm{~b}$ & $14.86 \mathrm{dA}$ & $10.33 \mathrm{bA}$ & $12.60 \mathrm{~b}$ \\
\hline 34 & $68.35 \mathrm{aA}$ & $67.03 \mathrm{aA}$ & $67.69 \mathrm{a}$ & $47.70 \mathrm{cB}$ & $57.23 \mathrm{aA}$ & $52.47 \mathrm{~b}$ & $20.65 \mathrm{dA}$ & $9.80 \mathrm{aB}$ & $15.23 \mathrm{c}$ \\
\hline 35 & $69.90 \mathrm{aA}$ & $67.76 \mathrm{aA}$ & $68.83 \mathrm{a}$ & $65.35 \mathrm{aA}$ & $60.23 \mathrm{aA}$ & $62.79 \mathrm{a}$ & $4.55 \mathrm{aA}$ & $7.53 \mathrm{aA}$ & $6.04 \mathrm{a}$ \\
\hline 41 & $66.40 \mathrm{bA}$ & $62.06 \mathrm{cB}$ & $64.23 \mathrm{~b}$ & $53.90 \mathrm{bA}$ & $48.60 \mathrm{cA}$ & $51.25 \mathrm{~b}$ & $12.50 \mathrm{bA}$ & $13.46 \mathrm{bA}$ & $12.98 \mathrm{~b}$ \\
\hline 42 & $69.25 \mathrm{aA}$ & $61.93 \mathrm{cB}$ & $65.59 \mathrm{~b}$ & $61.65 \mathrm{aA}$ & $50.60 \mathrm{cB}$ & $56.13 \mathrm{~b}$ & $7.60 \mathrm{aA}$ & $11.33 \mathrm{bA}$ & $9.47 \mathrm{a}$ \\
\hline 43 & $68.22 \mathrm{aA}$ & $62.65 \mathrm{cB}$ & $65.44 \mathrm{~b}$ & $59.00 \mathrm{bA}$ & $47.90 \mathrm{cB}$ & $53.45 \mathrm{~b}$ & $9.22 \mathrm{aA}$ & $14.75 \mathrm{dA}$ & $11.99 \mathrm{~b}$ \\
\hline 50 & $67.86 \mathrm{aA}$ & $63.90 \mathrm{bB}$ & $65.88 \mathrm{a}$ & $56.20 \mathrm{bA}$ & $55.85 \mathrm{aA}$ & $56.03 \mathrm{~b}$ & $11.66 \mathrm{bA}$ & $8.05 \mathrm{aA}$ & $9.86 \mathrm{a}$ \\
\hline 54 & $69.12 \mathrm{aA}$ & $67.06 \mathrm{aA}$ & $68.10 \mathrm{a}$ & $64.62 \mathrm{aA}$ & $58.73 \mathrm{aA}$ & $61.68 \mathrm{a}$ & $4.50 \mathrm{aA}$ & $8.33 \mathrm{aA}$ & $6.42 \mathrm{a}$ \\
\hline 59 & $64.35 \mathrm{bA}$ & $61.40 \mathrm{cA}$ & $62.88 \mathrm{c}$ & $41.92 \mathrm{cA}$ & $43.25 \mathrm{cA}$ & $42.59 \mathrm{~d}$ & $22.42 \mathrm{dA}$ & $18.15 \mathrm{dA}$ & $20.29 \mathrm{~d}$ \\
\hline 60 & $69.32 \mathrm{aA}$ & $64.33 \mathrm{bB}$ & $66.83 \mathrm{a}$ & $60.07 \mathrm{aA}$ & $52.00 \mathrm{bB}$ & $56.04 \mathrm{~b}$ & $9.25 \mathrm{aA}$ & $12.33 \mathrm{bA}$ & $10.79 \mathrm{~b}$ \\
\hline 61 & $68.40 \mathrm{aA}$ & $57.93 \mathrm{cB}$ & $63.17 \mathrm{c}$ & $44.80 \mathrm{cA}$ & $38.73 \mathrm{cA}$ & $41.77 \mathrm{~d}$ & $23.60 \mathrm{dA}$ & $19.20 \mathrm{dA}$ & $21.40 \mathrm{~d}$ \\
\hline 67 & $68.87 \mathrm{aA}$ & $62.13 \mathrm{cB}$ & $65.50 \mathrm{~b}$ & $53.95 \mathrm{bA}$ & $51.26 \mathrm{bA}$ & $52.61 \mathrm{~b}$ & $14.92 \mathrm{cA}$ & $10.86 \mathrm{bA}$ & $12.90 \mathrm{~b}$ \\
\hline 68 & $68.25 \mathrm{aA}$ & $64.46 \mathrm{bB}$ & $66.36 \mathrm{a}$ & $51.25 \mathrm{cA}$ & $49.00 \mathrm{cA}$ & $50.13 \mathrm{c}$ & $17.00 \mathrm{cA}$ & $15.46 \mathrm{dA}$ & $16.23 \mathrm{c}$ \\
\hline 71 & $65.47 \mathrm{bA}$ & $60.56 \mathrm{cB}$ & $63.02 \mathrm{~b}$ & $52.50 \mathrm{bA}$ & $42.26 \mathrm{cB}$ & $47.38 \mathrm{c}$ & $12.97 \mathrm{bA}$ & $18.30 \mathrm{dA}$ & $15.64 \mathrm{c}$ \\
\hline 72 & $68.40 \mathrm{aA}$ & $64.95 \mathrm{bB}$ & $66.68 \mathrm{a}$ & $62.50 \mathrm{aA}$ & $50.55 \mathrm{bB}$ & $56.63 \mathrm{~b}$ & $5.90 \mathrm{aB}$ & $14.40 \mathrm{cA}$ & $10.15 \mathrm{~b}$ \\
\hline 82 & $69.10 \mathrm{aA}$ & $61.25 \mathrm{cB}$ & $65.18 \mathrm{~b}$ & $44.60 \mathrm{cA}$ & $49.95 \mathrm{cA}$ & $47.28 \mathrm{c}$ & $24.50 \mathrm{dA}$ & $11.30 \mathrm{bB}$ & $17.90 \mathrm{c}$ \\
\hline 83 & $68.85 \mathrm{aA}$ & $65.85 \mathrm{aB}$ & $67.35 \mathrm{a}$ & $64.40 \mathrm{aA}$ & $56.85 \mathrm{aA}$ & $60.63 \mathrm{a}$ & $4.45 \mathrm{aA}$ & $9.00 \mathrm{aA}$ & $6.73 \mathrm{a}$ \\
\hline 84 & $69.30 \mathrm{aA}$ & $66.66 \mathrm{aA}$ & $67.98 \mathrm{a}$ & $63.55 \mathrm{aA}$ & $56.06 \mathrm{aA}$ & $59.81 \mathrm{a}$ & $5.75 \mathrm{aA}$ & $10.60 \mathrm{bA}$ & $8.18 \mathrm{a}$ \\
\hline 90 & $66.85 \mathrm{bA}$ & $63.40 \mathrm{bB}$ & $65.13 \mathrm{~b}$ & $54.70 \mathrm{bA}$ & $50.90 \mathrm{cA}$ & $52.80 \mathrm{~b}$ & $12.15 \mathrm{bA}$ & $12.50 \mathrm{bA}$ & $12.33 \mathrm{~b}$ \\
\hline 98 & $68.37 \mathrm{aA}$ & $64.90 \mathrm{aB}$ & $66.64 \mathrm{a}$ & $60.55 \mathrm{aA}$ & $51.55 \mathrm{bB}$ & $56.05 \mathrm{~b}$ & $7.82 \mathrm{aA}$ & $13.35 \mathrm{bA}$ & $10.59 \mathrm{~b}$ \\
\hline 103 & $64.27 \mathrm{bA}$ & $59.40 \mathrm{cB}$ & $61.84 \mathrm{c}$ & $33.05 \mathrm{cB}$ & $43.20 \mathrm{cA}$ & $38.13 \mathrm{~d}$ & $31.22 \mathrm{dA}$ & $16.20 \mathrm{~dB}$ & $23.71 \mathrm{~d}$ \\
\hline 104 & $67.40 \mathrm{aA}$ & $65.20 \mathrm{bA}$ & $66.30 \mathrm{a}$ & $58.32 \mathrm{bA}$ & $53.40 \mathrm{aA}$ & $55.86 \mathrm{~b}$ & $9.07 \mathrm{aA}$ & $11.80 \mathrm{bA}$ & $10.44 \mathrm{~b}$ \\
\hline IPR117 & $69.12 \mathrm{aA}$ & $64.55 \mathrm{bB}$ & $66.84 \mathrm{a}$ & $62.72 \mathrm{aA}$ & $48.75 \mathrm{cB}$ & $55.74 \mathrm{~b}$ & $6.40 \mathrm{aB}$ & $15.80 \mathrm{dA}$ & $11.10 \mathrm{~b}$ \\
\hline Mean $(\mathrm{m})$ & $67.97 \mathrm{a}$ & $63.81 \mathrm{~b}$ & 65.89 & $55.31 \mathrm{a}$ & $51.23 \mathrm{~b}$ & 53.27 & $12.66 \mathrm{a}$ & $12.58 \mathrm{a}$ & 12.62 \\
\hline$>\mathrm{QM} /<\mathrm{Qm}^{1}$ & & & - & 4. & & - & 6. & & - \\
\hline $\mathrm{CV}(\%)^{2}$ & 3.07 & 3.36 & 3.21 & 12.47 & 6.36 & 10.13 & 13.35 & 20.61 & 18.77 \\
\hline $\mathrm{CV}_{\mathrm{g}}(\%)^{3}$ & 1.63 & 3.38 & & 14.15 & 9.39 & & 53.38 & 23.83 & \\
\hline Prob. F Test ${ }^{4}$ & $0.20^{* *}$ & $0.00 * *$ & - & $0.00 * *$ & $0.00 * *$ & - & $0.00 * *$ & $0.00 * *$ & - \\
\hline Prob. F Test $\mathrm{G}^{5}$ & - & - & $0.00 * *$ & - & - & $0.00 * *$ & - & - & $0.00 * *$ \\
\hline Prob. F Test $\mathrm{E}^{6}$ & - & - & $0.00 * *$ & - & - & $51.76^{\mathrm{ns}}$ & - & - & $100.00^{\text {ns }}$ \\
\hline Prob. F Test $\mathrm{G} \times \mathrm{E}^{7}$ & - & - & $0.13^{* *}$ & - & - & $0.00 * *$ & - & - & $0.00 * *$ \\
\hline eanc recorded for the & 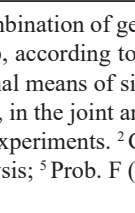 & 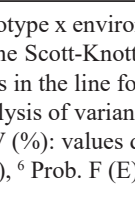 & 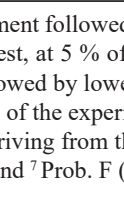 & 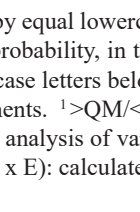 & 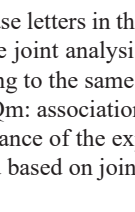 & lumn ( & pe) and by & 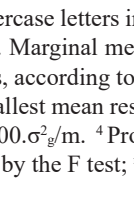 & 5 \\
\hline
\end{tabular}


ranged from $0.08 \%$ to $9.61 \%$, with a mean value of $3.64 \%$ (Table 3). A lower incidence of white-belly

grains was observed in Anchieta, where 28 of the varieties presented lower white-belly grain rates,

Table 3. Percentage of white-belly and chalky rice whole grains based on joint analysis of variance, in Anchieta (Anc) and Florianópolis (Fln), in 2018/2019.

\begin{tabular}{|c|c|c|c|c|c|c|}
\hline \multirow{2}{*}{ Local varieties } & \multicolumn{3}{|c|}{ White-belly grains $(\%)$} & \multicolumn{3}{|c|}{ Chalky grains (\%) } \\
\hline & Anc & Fln & Mean & Anc & $F \ln$ & Mean \\
\hline 7 & $2.71 \mathrm{aA}$ & $3.34 \mathrm{bA}$ & $3.03 \mathrm{~d}$ & $0.07 \mathrm{aA}$ & $0.09 \mathrm{aA}$ & $0.08 \mathrm{a}$ \\
\hline 10 & $4.78 \mathrm{dA}$ & $8.68 \mathrm{eB}$ & $6.73 \mathrm{~g}$ & $0.09 \mathrm{aA}$ & $0.10 \mathrm{aA}$ & $0.10 \mathrm{a}$ \\
\hline 12 & $0.89 \mathrm{aA}$ & $4.64 \mathrm{cB}$ & $2.77 \mathrm{~d}$ & $0.07 \mathrm{aA}$ & $0.09 \mathrm{aA}$ & $0.08 \mathrm{a}$ \\
\hline 13 & $0.08 \mathrm{aA}$ & $1.78 \mathrm{bB}$ & $0.93 \mathrm{~b}$ & $0.06 \mathrm{aA}$ & $0.50 \mathrm{bA}$ & $0.28 \mathrm{a}$ \\
\hline 14 & $0.57 \mathrm{aA}$ & $2.64 \mathrm{bB}$ & $1.61 \mathrm{~b}$ & $0.10 \mathrm{aA}$ & $0.69 \mathrm{bA}$ & $0.40 \mathrm{a}$ \\
\hline 17 & $3.24 \mathrm{bA}$ & $6.79 \mathrm{eB}$ & $5.02 \mathrm{f}$ & $0.09 \mathrm{aA}$ & $0.71 \mathrm{bA}$ & $0.40 \mathrm{a}$ \\
\hline 19 & $5.82 \mathrm{dA}$ & $6.06 \mathrm{eA}$ & $5.94 \mathrm{~g}$ & $0.14 \mathrm{aA}$ & $0.10 \mathrm{aA}$ & $0.12 \mathrm{a}$ \\
\hline 20 & $3.24 \mathrm{bB}$ & $1.94 \mathrm{bA}$ & $2.59 \mathrm{c}$ & $0.09 \mathrm{aA}$ & $0.88 \mathrm{aB}$ & $0.49 \mathrm{a}$ \\
\hline 22 & $0.44 \mathrm{aA}$ & $3.41 \mathrm{cB}$ & $1.93 \mathrm{c}$ & $0.04 \mathrm{aA}$ & $1.00 \mathrm{bB}$ & $0.52 \mathrm{a}$ \\
\hline 24 & $1.03 \mathrm{aA}$ & $5.07 \mathrm{~dB}$ & $3.05 \mathrm{~d}$ & $0.08 \mathrm{aA}$ & $0.90 \mathrm{aB}$ & $0.09 \mathrm{a}$ \\
\hline 29 & $0.08 \mathrm{aA}$ & $8.16 \mathrm{eB}$ & $4.12 \mathrm{e}$ & $0.16 \mathrm{aA}$ & $1.54 \mathrm{cB}$ & $0.85 \mathrm{~b}$ \\
\hline 31 & $4.00 \mathrm{cA}$ & $9.61 \mathrm{eB}$ & $6.81 \mathrm{~g}$ & $1.72 \mathrm{bA}$ & $2.16 \mathrm{dA}$ & $1.94 \mathrm{e}$ \\
\hline 32 & $4.78 \mathrm{dA}$ & $5.59 \mathrm{dA}$ & $5.19 \mathrm{f}$ & $0.10 \mathrm{aA}$ & $0.09 \mathrm{aA}$ & $0.10 \mathrm{a}$ \\
\hline 34 & $1.76 \mathrm{aA}$ & $4.35 \mathrm{cB}$ & $3.06 \mathrm{~d}$ & $0.08 \mathrm{aA}$ & $0.77 \mathrm{bA}$ & $0.43 \mathrm{a}$ \\
\hline 35 & $0.08 \mathrm{aA}$ & $0.08 \mathrm{aA}$ & $0.08 \mathrm{a}$ & $0.08 \mathrm{aA}$ & $0.61 \mathrm{bA}$ & $0.35 \mathrm{a}$ \\
\hline 41 & $8.35 \mathrm{eB}$ & $6.05 \mathrm{dA}$ & $7.20 \mathrm{~g}$ & $0.09 \mathrm{aA}$ & $0.10 \mathrm{aA}$ & $0.10 \mathrm{a}$ \\
\hline 42 & $0.51 \mathrm{aA}$ & $2.38 \mathrm{bB}$ & $1.45 \mathrm{~b}$ & $0.08 \mathrm{aA}$ & $0.78 \mathrm{bA}$ & $0.43 \mathrm{a}$ \\
\hline 43 & $0.60 \mathrm{aA}$ & $3.76 \mathrm{cB}$ & $2.18 \mathrm{c}$ & $0.08 \mathrm{aA}$ & $1.57 \mathrm{cB}$ & $0.83 \mathrm{~b}$ \\
\hline 50 & $1.20 \mathrm{aA}$ & $3.04 \mathrm{bB}$ & $2.12 \mathrm{c}$ & $0.42 \mathrm{aA}$ & $1.22 \mathrm{cB}$ & $0.82 \mathrm{~b}$ \\
\hline 54 & $0.10 \mathrm{aA}$ & $1.49 \mathrm{aB}$ & $0.79 \mathrm{~b}$ & $0.02 \mathrm{aA}$ & $0.08 \mathrm{aB}$ & $0.05 \mathrm{a}$ \\
\hline 59 & $8.13 \mathrm{eB}$ & $4.27 \mathrm{cA}$ & $6.20 \mathrm{~g}$ & $0.08 \mathrm{aA}$ & $0.11 \mathrm{aA}$ & $0.10 \mathrm{a}$ \\
\hline 60 & $0.73 \mathrm{aA}$ & $3.86 \mathrm{cB}$ & $2.30 \mathrm{c}$ & $0.14 \mathrm{aA}$ & $1.55 \mathrm{cB}$ & $0.85 \mathrm{~b}$ \\
\hline 61 & $4.31 \mathrm{cB}$ & $1.99 \mathrm{bA}$ & $3.15 \mathrm{c}$ & $0.13 \mathrm{aA}$ & $1.30 \mathrm{cB}$ & $0.72 \mathrm{~b}$ \\
\hline 67 & $0.09 \mathrm{aA}$ & $0.51 \mathrm{aA}$ & $0.30 \mathrm{a}$ & $0.09 \mathrm{aA}$ & $2.64 \mathrm{~dB}$ & $1.37 \mathrm{~d}$ \\
\hline 68 & $1.93 \mathrm{cA}$ & $2.60 \mathrm{bA}$ & $2.27 \mathrm{c}$ & $0.09 \mathrm{aA}$ & $0.74 \mathrm{bA}$ & $0.42 \mathrm{a}$ \\
\hline 71 & $8.07 \mathrm{eB}$ & $5.35 \mathrm{dA}$ & $6.71 \mathrm{~g}$ & $0.26 \mathrm{aA}$ & $0.12 \mathrm{aA}$ & $0.19 \mathrm{a}$ \\
\hline 72 & $3.70 \mathrm{cB}$ & $1.29 \mathrm{aA}$ & $2.50 \mathrm{c}$ & $0.63 \mathrm{aA}$ & $1.53 \mathrm{cB}$ & $1.08 \mathrm{~b}$ \\
\hline 82 & $2.57 \mathrm{bA}$ & $1.65 \mathrm{aB}$ & $2.11 \mathrm{c}$ & $0.11 \mathrm{aB}$ & $1.07 \mathrm{bA}$ & $0.59 \mathrm{~b}$ \\
\hline 83 & $0.04 \mathrm{aA}$ & $0.08 \mathrm{aA}$ & $0.06 \mathrm{a}$ & $0.04 \mathrm{aA}$ & $0.08 \mathrm{aA}$ & $0.06 \mathrm{a}$ \\
\hline 84 & $0.06 \mathrm{aA}$ & $0.99 \mathrm{aA}$ & $0.53 \mathrm{a}$ & $0.06 \mathrm{aA}$ & $0.71 \mathrm{bA}$ & $0.39 \mathrm{a}$ \\
\hline 90 & $1.76 \mathrm{bA}$ & $4.10 \mathrm{cB}$ & $2.93 \mathrm{~d}$ & $0.11 \mathrm{aB}$ & $1.37 \mathrm{cA}$ & $0.74 \mathrm{~b}$ \\
\hline 98 & $0.70 \mathrm{aA}$ & $1.46 \mathrm{bA}$ & $1.08 \mathrm{~b}$ & $0.10 \mathrm{aB}$ & $1.20 \mathrm{cA}$ & $0.65 \mathrm{~b}$ \\
\hline 103 & $5.15 \mathrm{~dB}$ & $3.24 \mathrm{bB}$ & $4.20 \mathrm{e}$ & $2.34 \mathrm{bB}$ & $3.12 \mathrm{dA}$ & $2.73 \mathrm{f}$ \\
\hline 104 & $2.33 \mathrm{bB}$ & $6.39 \mathrm{eB}$ & $4.36 \mathrm{e}$ & $0.19 \mathrm{aA}$ & $1.42 \mathrm{cB}$ & $0.80 \mathrm{~b}$ \\
\hline IPR117 & $0.08 \mathrm{aA}$ & $0.69 \mathrm{aA}$ & $0.39 \mathrm{a}$ & $0.08 \mathrm{aA}$ & $1.96 \mathrm{cB}$ & $1.02 \mathrm{~b}$ \\
\hline Mean $(m)$ & $2.40 \mathrm{a}$ & $3.64 \mathrm{~b}$ & 3.02 & $0.23 \mathrm{a}$ & $0.92 \mathrm{~b}$ & 0.57 \\
\hline$>\mathrm{QM} /<\mathrm{Qm}^{1}$ & & & - & & & - \\
\hline $\mathrm{CV}(\%)^{2}$ & 13.38 & 20.38 & 20.12 & 22.27 & 16.07 & 19.89 \\
\hline $\mathrm{CV}_{\mathrm{g}}(\%)^{3}$ & 101.16 & 66.61 & 69.11 & 165.51 & 76.46 & 89.36 \\
\hline Prob. F Test ${ }^{4}$ & $0.00 * *$ & $0.00 * *$ & - & $0.00 * *$ & $0.00 * *$ & \\
\hline Prob. F Test $\mathrm{G}^{5}$ & - & - & $0.00 * *$ & - & - & $0.00 * *$ \\
\hline Prob. F test $\mathrm{E}^{6}$ & - & - & $51.09^{\mathrm{ns}}$ & - & - & $51.09^{\mathrm{ns}}$ \\
\hline Prob. F test $\mathrm{G} \times \mathrm{E}^{7}$ & - & - & $0.00 * *$ & - & - & $0.00 * *$ \\
\hline $\begin{array}{l}\text { Means recorded for the genoty } \\
\text { belong to the same group, ac } \\
\text { in the column and marginal } n \\
\text { test, at } 5 \% \text { of probability, in } \\
\text { the joint analysis of the expe } \\
\text { based on individual analysis. } \\
\text { at } 5 \% \text {, by the } \mathrm{F} \text { test. }\end{array}$ & $\begin{array}{l}\text { ent interactio } \\
\text { Scott-Knott te } \\
\text { the line follo } \\
\text { is of variance } \\
\text { \%): values res } \\
\text { Prob. F (E) a }\end{array}$ & $\begin{array}{l}\text { ed by equal } \\
\% \text { of probab } \\
\text { lowercase le } \\
\text { xperiments. } \\
\text { rom the anal }\end{array}$ & $\begin{array}{l}\text { se letters in } \\
\text { he joint analy } \\
\text { ong to the sar } \\
<Q m \text { : associa } \\
\text { ariance of the }\end{array}$ & $\begin{array}{l}\mathrm{nn} \text { (genotyp } \\
\text { ariance of th } \\
\text {, for their } \mathrm{r} \\
\text { ween the lar } \\
\text { nents. }{ }^{3} \mathrm{CV}_{\mathrm{g}} \\
\text { lysis. }{ }^{* *} \mathrm{Sig}\end{array}$ & $\begin{array}{l}\text { uppercase } \\
\text { ents. Marg } \\
\text { effects, acce } \\
\text { ee smallest } \\
d \text { as } 100 . \sigma^{2} \\
1 \% \text {, by th }\end{array}$ & $\begin{array}{l}\text { the line (s } \\
\text { s of genoty } \\
\text { the Scott-K } \\
\text { idual square } \\
\text { b. F: calculc } \\
\text { not signific }\end{array}$ \\
\hline
\end{tabular}


in comparison to Florianópolis, based on the joint analysis of variance.

The incidence of white-belly in whole grains was higher in varieties classified as mid-sized grains, which resemble special grain types, with regard to shape, as well as grains traditionally used in risotto, which present a higher rate of white-belly or white-core grains. The mean value recorded for chalky grains, in Anchieta, was $0.23 \%$, with values ranging from $0.06 \%$ to $2.34 \%$; while that recorded for chalky grains in Florianópolis was $0.92 \%$, with values ranging from $0.09 \%$ to $3.12 \%$. Only two varieties grown in Anchieta recorded values higher than the standard accepted by processing industries $(1 \%)$, whereas fifteen varieties grown in Florianopolis recorded values higher than the acceptable limit set for chalky grains.

According to Facchinelo (2017), the quality attributes of rice grains are also significantly affected by the genotype $\mathrm{x}$ environment interaction. The milling yield recorded significantly different values $(p \leq 0.05)$, based on genotype, environment and genotype $\mathrm{x}$ environment interaction. Jing et al. (2010) recorded similar results for five genotypes grown in different environments.

Whole and broken grains recorded significantly different values $(\mathrm{p} \leq 0.05)$, based on genotype and environment, but not on genotype $\mathrm{x}$ environment interaction (Table 3). These values were opposed to the ones observed by Blanche et al. (2009), who reported a significant genotype $\mathrm{x}$ environment interaction and a large magnitude for the variable 'whole grain yield'.

With respect to these first three variables (milling yield, whole and broken grains), which are the main factors influencing the prices paid to farmers, the genotypes have shown intrinsic differences among themselves and were influenced by different environments. This outcome emphasizes the significant role played by the genotype $\mathrm{x}$ environment interaction for milling yield.

White-belly and chalky variables recorded significant differences $(p \leq 0.05)$ based on genotype and genotype $\mathrm{x}$ environment interaction, and non-significant differences based on environment (Table 3).

Identifying more stable genotypes is an alternative to minimize the effects of the genotype $\mathrm{x}$ environment interaction (Borém \& Nakano 2015). Based on the mean stability ranking (Table 4), which
Table 4. Ranking of the ten most stable dryland rice varieties grown in Anchieta and Florianópolis, based on milling yield (MYI), whole grains (WGR), broken grains (BGR), white-belly (WBE) and chalky (CGR) grains, in the 2018/2019 crop.

\begin{tabular}{crrrrrc}
\hline Varieties & MYI & WGR & BGR & WBE & CGR & Ranking \\
\hline 32 & 1 & 9 & 16 & 9 & 2 & 1 \\
35 & 5 & 11 & 8 & 1 & 13 & 2 \\
68 & 18 & 4 & 4 & 7 & 16 & 3 \\
54 & 4 & 14 & 12 & 13 & 9 & 4 \\
83 & 11 & 18 & 17 & 2 & 8 & 5 \\
41 & 21 & 12 & 3 & 19 & 3 & 6 \\
10 & 20 & 8 & 1 & 31 & 1 & 7 \\
59 & 10 & 3 & 14 & 30 & 6 & 8 \\
50 & 19 & 1 & 10 & 15 & 22 & 9 \\
84 & 7 & 16 & 19 & 11 & 17 & 10 \\
\hline
\end{tabular}

was calculated according to the mean position of each variety, regarding the stability of each variable, two varieties stood out among the ten most stable ones, and recorded the highest yield and whole grain rates (varieties 35 and 54). The variety 32 stood out as the most stable for yield and as the second most stable for chalky grains; the variety 35 stood out as the most stable for white-belly and as the fifth most stable variety for milling yield; and the variety 10 stood out as the most stable for broken and chalky grains.

Milling yield values higher than $69 \%$ and whole grain values higher than $62 \%$ were recorded for the eight varieties presenting the best industrial quality $(7,12,13,24,35,54,72$ and 83), in Anchieta. These varieties are promising alternatives to help expanding the rice production to the local or regional market, mainly if taking into consideration the technology level adopted by farmers, or local varieties not subjected to breeding. Besides showing a high milling yield and whole grain yield, the varieties 13 and 72 also stood out for the superior grain yield in Anchieta (Maghelly 2020).

The analyzed data enable farmers to define the most suitable varieties to expand their production and sell it in local markets, by giving priority to the ones presenting the best industrial yield and adjusted (according to grain class) to local mill regulations, mainly the ones set by cooperatives and farmers' associations. Further studies should focus on evaluating the potential of these local varieties in other environments, as well as on assessing their biochemical, nutritional and cooking quality parameters. 


\section{CONCLUSION}

The investigated local varieties showed differences for industrial performance and stability, based on all evaluated variables. The industrial yield was superior for all the characteristics in Anchieta, region of origin for the varieties. The varieties presenting the best industrial performance for milling yield, whole and broken grains $(7,12,13$, $24,35,54,72$ and 83 ) recorded values equal to or higher than the ones recorded for modern improved dryland and irrigated rice varieties. Values recorded for white-belly and chalky grains were within the limits accepted by the market for the majority of the varieties, both in Anchieta and Florianópolis.

\section{ACKNOWLEDGMENTS}

The authors are grateful to the Universidade Federal de Santa Catarina (UFSC) experimental farm team, Cooperanchieta, Estância da Várzea agricultural condominium and the Uliana family.

\section{REFERENCES}

ARTIGIANI, A. C. C. A.; CRUSCIOL, C. A. C.; ARF, O.; ALVAREZ, R. C. F.; NASCENTE, A. S. Produtividade e qualidade industrial do arroz de terras altas em função da disponibilidade hídrica e adubação. Pesquisa Agropecuária Tropical, v. 42, n. 3, p. 340-349, 2012.

BLANCHE, S. B.; UTOMO, H. S.; WENEFRIDA, I.; MYERS, G. O. Genotype $\times$ environment interactions of hybrid and varietal rice cultivars for grain yield and milling quality. Crop Science, v. 49, n. 6, p. 2011-2018, 2009.

BORÉM, A.; NAKANO, P. H. Arroz: do plantio à colheita. Viçosa: Ed. UFV, 2015.

BRASIL. Ministério da Agricultura, Pecuária e Abastecimento. Instrução Normativa $\mathrm{n}^{\circ}$ 6, de 16 de fevereiro de 2009. Aprova o regulamento técnico do arroz, definindo o seu padrão oficial de classificação, com os requisitos de identidade e qualidade, a amostragem, o modo de apresentação e a marcação ou rotulagem. Diário Oficial da República Federativa do Brasil: seção 1, Brasília, DF, p. 3, 17 fev. 2009.

BRASIL. Ministério da Agricultura, Pecuária e Abastecimento. Instrução Normativa $\mathrm{n}^{\circ} 2$, de 6 de fevereiro de 2012. Aprova o regulamento técnico do arroz, definindo o seu padrão oficial de classificação, com os requisitos de identidade e qualidade, a amostragem, o modo de apresentação e a marcação ou rotulagem. Diário Oficial da República Federativa do Brasil: seção 1, Brasília, DF, p. 3, 7 fev. 2012.

CASTRO, E. da M.; VIEIRA, N. R. A.; RABELO, R. R.; SILVA, S. A. da. Qualidade de grãos em arroz. Santo Antônio de Goiás: Embrapa Arroz e Feijão, 1999. (Circular técnica, 34).

CENTRODE ESTUDOS AVANÇADOS EMECONOMIA APLICADA (Cepea). Metodologia do arroz em casca ESALQ/SENAR-RS. 2015. Disponível em: https://www. cepea.esalq.usp.br/br/metodologia/metodologia-do-arrozem-casca-esalq-senar-rs.aspx. Acesso em: mar. 2020.

CRUZ, C. D. Genes: software para análise de dados em estatística experimental e em genética quantitativa. Acta Scientiarum Agronomy, v. 35, n. 3, p. 271-276, 2013.

CRUZ, C. D.; REGAZZI, A. J. Modelos biométricos aplicados ao melhoramento genético. Viçosa: Ed. UFV, 2001.

EMPRESA BRASILEIRA DE PESQUISA AGROPECUÁRIA(Embrapa). Catálogo de cultivares de arroz: safra 2017/2018. Santo Antônio de Goiás: Embrapa Arroz e Feijão, 2018.

EMPRESA BRASILEIRA DE PESQUISA AGROPECUÁRIA (Embrapa). Dados conjunturais da produção de arroz (Oryza sativa L.) no Brasil (1986 a 2018): área, produção e rendimento. Santo Antônio de Goiás: Embrapa Arroz e Feijão, 2019.

FACCHINelo, P. H. K. Parâmetros Genéticos e correlações para caracteres de qualidade de grãos em arroz irrigado. 2017. Dissertação (Mestrado em Ciências) - Universidade Federal de Pelotas, Pelotas, 2017.

FARIAS FILHO, M. S.; FERRAZ JUNIOR, A. S. L. A cultura do arroz em sistema de vazante na baixada maranhense, periferia do sudeste da Amazônia. Pesquisa Agropecuária Tropical, v. 39, n. 2, p. 82-91, 2009.

INSTITUTO BRASILEIRO DE GEOGRAFIA E ESTATÍSTICA (IBGE). Censo 2010. 2010. Disponível em: http://www.censo2010.ibge.gov.br. Acesso em: mar. 2020.

JING, Q.; SPIERTZ, J.; HENGSDIJK, H.; KEULEN, H.; CAO, W.; DAI, T. Adaptation and performance of rice genotypes in tropical and subtropical environments. NJAS - Wageningen Journal of Life Sciences, v. 57, n. 2, p. 149-157, 2010.

KIBANDA, J. M. N.; LUZI-KIHUPI, A. Influence of genetic and genotype $\mathrm{x}$ environment interaction on quality of rice grain. African Crop Science Journal, v. 15, n. 4, p. 173-182, 2007.

MAGHELLY, O. R. Potencial genético de variedades locais de arroz de sequeiro do oeste catarinense. 2020. Tese (Doutorado em Recursos Genéticos Vegetais) - 
Universidade Federal de Santa Catarina, Florianópolis, 2020.

MARIOTTI, J. A.; OARZABAL, E. S.; OSA, J. M.; BULACIO, A. N. R.; ALMADA, G. H. Analisis de stabilidad y adaptabilidad de genótipos de cãna de azúcar: I. Interacciones dentro de una localidad experimental. Revista Agronómica Norte Argentina, v. 13, n. 114, p. 405412, 1976.

PEREIRA, J. A.; RANGEL, P. H. N. Produtividade e qualidade de grãos de arroz irrigado no Piauí. Ciência e Agrotecnologia, v. 25, n. 3, p. 569-575, 2001.

PIMENTEL-GOMES, F. Curso de estatística experimental. 13. ed. Piracicaba: Nobel, 1990.

PINTO, T. T.; OGLIARI, J. B.; MAGHELLY, O. R. Phenotypic characterization of dryland rice (Oryza sativa L.) germplasm conserved in situ (on farm) in a crop-diversity microcenter in southern Brazil. Genetic
Resources and Crop Evolution, v. 66, n. 2, p. 415-427, 2019.

SANTOS, A. B.; STONE, L. F.; VIEIRA, N. R. A. $A$ cultura do arroz no Brasil. Santo Antônio de Goiás: Embrapa Arroz e Feijão, 2006.

SANTOS, T. P. B. Características fisicas e químicas dos grãos gessados e seus efeitos na qualidade do arroz. 2012. Dissertação (Mestrado em Ciência e Tecnologia de Alimentos) - Universidade Federal de Goiás, Goiânia, 2012.

SEARLE, S. R.; CASELLA, G.; McCULLOCH, C. E. Variance components. New York: John Wiley \& Sons, 1992.

SMIDERLE, O. J.; DIAS, C. T. S. Época de colheita e qualidade fisiológica de sementes em arroz irrigado (Oryza sativa cv. BRS Roraima). Pesquisa Agropecuária Tropical, v. 38, n. 3, p. 188-194, 2008. 